\title{
The Use of Formal Intergovernmental Service Agreements: Does Government Structure Make A Difference?
}

\author{
Michael W. Hirlinger, Oklahoma State University \\ Robert E. England, Oklahoma State University
}

This study is concerned with the effect municipal government structure has on intergovernmental contracting. In addition, the impact of four other types of factors on the decision to enter into intergovernmental arrangements is examined--supply (cost savings), fiscal pressures, political influences, and legal constraints. The analysis also distinguishes between two different types of intergovernmental agreements--complete service contracting and joint contracting. Based on a sample of 614 U.S. cities, the findings indicate that municipal governments with reform structures (e.g., council-manager form of government, at-large elections, nonpartisan ballots) are significantly more likely to engage in complete intergovernmental service contracting than their unreformed counterparts. When considering joint contracting with other governments, though, government structure does not appear to be an important factor.

In response to increasing fiscal pressures along with citizens' demands to do more with less, public officials have sought ways to curb the rising cost of government services without reducing service quality or raising taxes (Clark and Ferguson 1983). Thus, public officials increasingly have explored alternatives to traditional government production of services. Of the variety of alternative approaches to public service delivery, contracting out has garnered the most attention.

As Kettl (1988, 23-24) notes, contracting for services generally is attractive for three reasons: (1) governments may be able to save money, (2) governments often need goods and services that are not available in the public sector, and (3) contracting sidesteps many governmental restraints. Despite these advantages, the privatization movement has been severely criticized (see Sullivan 1987; Moe 1987; Hanke 1987; Kettl 1988; Morgan and England 1988). Most government contracting takes place at the local level, and takes the form of contracting with private sector vendors or their governments. For the most part, the alternative service delivery literature focuses primarily on contracting out to the private sector (see for example Berenyi 1981; Hatry and Valente 1983; Stevens 1984; DeHoog 1985) and whether or not such contracting results in cost savings (Ahlbrandt 1974; Savas 1977; Stevens 1984). Some works have attempted to isolate those influences leading to contracting out decisions (Sonenblum, Kirlin, and Ries 1977; Florestano and Gordon 1980; Morgan, Meyer, and England 1981; Ferris 1986; Ferris and Graddy 1988; Morgan, England, and 
Hirlinger 1988). However, only a few efforts have been made to examine systematically those forces leading to intergovernmental contracting, and these tend to be limited either to certain geographical areas (Marando 1968; Sonenblum, Kirlin, and Ries 1977; Miller 1981; Hoch 1985) or individual services (Mehay 1979; Baer 1982).

The purpose of this research is to identify the various forces that seem to affect the decision by local governments to enter into service agreements with other units of government. Given the theoretical as well as the administrative implications associated with the urban reform movement, of particular concern here is the effect of government structure on intergovernmental contracting. While research has shown that council-manager cities are more likely to pursue service contracts with the private sector than mayor-council cities, the effects of government structure on intergovernmental service contracting behavior have been ignored. How important is government structure when intergovernmental service arrangements are considered by municipalities, since different factors appear to be more salient to private contracting than interlocal contracting (Morgan et al.1988)? How does its impact on the decision to enter into intergovernmental contracts compare to that of other relevant factors, such as supply (cost savings), fiscal pressures, political pressures, and legal constraints?

\section{Factors Influencing The Decision To Contract With Other Governments}

Contracts with other units of government represent one of several basic options available to cities searching for alternatives to the traditional delivery of urban services by municipal work forces. Although core urban services generally remain in municipal hands (e.g., police, fire, streets), the use of intergovernmental service agreements is more common than many realize. Zimmerman's (1973) early nationwide survey shows that some 61 percent of responding cities provide services through intergovernmental agreements. Sonenblum et al.'s (1977) study of California local governments shows that about half of all municipal services are provided through a variety of such arrangements. ACIR's $(1985,25)$ survey of the use of intergovernmental service agreements reveals that 52 percent of responding municipalities have written service contracts. Other studies have also found extensive utilization of the interjurisdictional service agreement, especially for the delivery of police services (Friesema 1971; Tees and Stanford 1972; 
McDavid 1977). In short, as community needs and problems grow, the use of formal cooperative arrangements among local governments has greatly increased in an effort to meet the challenges of adequate services and facilities.

By building on the works of Sonenblum et al. (1977) and Ferris (1986), it is possible to identify several factors that may be responsible for facilitating the increased usage of intergovernmental service agreements by municipalities. The contention here is that cities are more likely to turn to other governments for the delivery of services when (1) reform characteristics (e.g., city manager, nonpartisan ballots, at-large elections) are present within the municipality's structure, (2) cost savings are likely, (3) fiscal pressures are great, (4) political opposition is weak, and (5) state legal requirements concerning interlocal contracting are minimal.

\section{Government Structure}

The structure of government may affect the willingness or ability of local officials to consider intergovernmental agreements. Of particular concern is the impact of the urban reform movement of the late 1800 s and early 1900 s on urban policy making. The standard comparative indicators of government structure are whether or not the municipality possesses the "reformed" traits of a city manager as chief executive or nonpartisan or at-large elections of councilmen. It is generally claimed that such reform characteristics eliminate the "political machine" and give executive leadership a managerial ideology which abjures factional politics.

Researchers traditionally have been interested in the effects of government structure on local policy. For example, cities with the council-manager form of government, at-large representation, and nonpartisan elections have been found to spend and tax at lower levels than so-called unreformed cities (see Lineberry and Fowler 1967; Lyons 1978). City manager governments are believed to be more sensitive to cost considerations and more capable of resisting external political influences than their mayoral counterparts (Martin 1986; Morgan 1989). Evidence also suggests the presence of a city manager may contribute to a locality's willingness to pursue innovative or creative strategies when faced with fiscal problems (Levine et al. 1981, 214215). In general, conventional wisdom suggests that the centralized authority characteristic of a council-manager form of government may 
indeed facilitate change, risk taking, and resource reallocation. One might expect, then, that city manager cities would be somewhat more inclined than their mayoral counterparts to engage in greater contracting behavior.

Government structure is represented by the elements of reform--city manager, at-large representation, nonpartisan elections. We classified cities as having no reform elements, one reform element, two reform elements, or three reform elements.

\section{Cost Savings}

According to the bulk of the literature the most common justification for contracting out is the potential for saving money (see Fisk, Kiesling, and Muller 1978; Florestano 1982; Savas 1982). These potential cost savings can be derived from several sources. Such sources include the introduction of competition and its attendant emphasis on efficiency (Bennett and Johnson 1980), economies of scale, and labor costs.

Indeed, most empirical research on studies of local service production in specific service areas shows that cost savings can be realized from contracting out because of competition, scale economies, and sector differences in labor costs. Stevens' (1984) study on contracting activity in the Los Angeles area--which included such services as street cleaning and maintenance, refuse collection, janitorial services, traffic signal maintenance--suggests that contracting out not only saves money but also has no adverse effect on service quality.

The quest for efficiency may not be as relevant when cities decide to contract with other governments as when private sector producers are sought for the delivery of municipal services. Research on interlocal agreements in the Los Angeles area suggests that cities frequently pursue such arrangements not so much for efficient service provision, but in order to use municipal incorporation (and subsequent contracting) as a means of protecting territorial interests (Hoch 1985) or avoiding high taxes (Miller 1981, 78-82). Furthermore, interlocal service agreements are often used not so much for the purpose of achieving efficient service production but as a means to solve translocal problems affecting several adjacent local governments. Thus, in certain instances, cooperating interlocally to solve common local problems may be a more important consideration than efficiency gains when cities decide to enter into an intergovernmental contract. 
Nevertheless, local officials continue to claim that the search for economies of scale is the number one reason for entering into intergovernmental contracts (ACIR 1985). The importance of an adequate number of alternative suppliers is indeed a related factor in the contracting decision. In fact, the scarcity of suppliers has been a significant barrier to increased contracting for social and other services among cities in rural areas and small communities (Straussman and Farie 1981; DeHoog 1985). Cities within metropolitan jurisdictions enjoy greater availability of external producers. Since one of the primary components that must exist before cost savings can be realized is the availability of external suppliers, metropolitan status is employed to represent the supply factor. A dummy variable--NONMSA/MSA--is included to capture this effect.

\section{Fiscal Pressures}

According to several studies (Berenyi 1981; Kirlin, Ries, and Sonenblum 1977; Ferris and Graddy 1988; Morgan, et al. 1988), a major impetus in the search for municipal service delivery alternatives is fiscal stress. Contracting out, with the growing reputation as a cost saver, should prove to be an attractive option under such adverse conditions. Berenyi $(1981,34)$, for example, reports that some actual or perceived fiscal stringency was present to some extent in each of her ten cities that had shifted to external production of refuse collection.

The use of interlocal service agreements, however, may not be influenced much by immediate fiscal pressures because most are infor$\mathrm{mal}$ in nature and of a long duration. Interlocal agreements are also employed on a fairly routinized basis and change only incrementally over time. As Marando $(1968,187)$ notes for the Detroit area, "cooperative agreements once entered into are quite stable with some agreements having been in existence for over sixty years." Research has shown that cities experiencing fiscal pressures are more likely to seek private producers instead of government suppliers as an alternative to service delivery (Morgan et al. 1988).

A major source of fiscal pressure for many localities is legislatively imposed tax limitations. Fiscal limits, either statutory or constitutional in nature, reduce the flexibility of local governments to control their financial destiny. When these limits are binding, local governments have no choice but to seek different ways of operating. Therefore, in those communities where political opposition to higher taxes 
exists, which is reflected through actual legal limits on taxing authority, one would expect more contracting out in general. The fiscal measure included in the analysis is state imposed tax limitations, which is represented by a categorical variable indicating whether the city is operating under any form of externally imposed tax limit.

\section{Political Pressures}

Political influences are often considered to have a major effect on the contracting decision. As Ferris (1986) suggests, even if cost savings can be demonstrated and fiscal pressures are strong, there are political forces that counteract incentives to contract out. By political opposition Ferris means primarily resistance by service recipients. Indeed, Hatry $(1983,17)$ reports that among 39 California cities, problems with the "public to be served" was the most frequently listed obstacle encountered in contracting out. In particular, Ferris (1986) contends that dependent populations--blacks, low income, and the elderly--tend to perceive contracting as a threat to service continuance. Such groups often feel that any elimination of a governmental department signals a weakening public sector commitment to the particular service. If any reduction in service occurs, it often hits programs-welfare, health, and recreation--which tend to be aimed primarily at dependent groups (Morgan and England 1988). Furthermore, such groups may be fearful of contracting because the government has served as a valuable employment outlet, especially for minorities. Pascal (1981) reports that governments of many large cities have twice the proportion of minorities in their workforce as does the general economy. Another study concludes that the use of alternative service delivery approaches may curtail an important avenue of social and economic mobility for minorities (Suggs 1986). Thus, the proportions of the population that are black, low income, and age 65 or over will be used as surrogate measures of community political pressures.

Others argue that municipal employees are the principal and most powerful political opponents of contracting out (Shulman 1982), as well as of increased usage of alternative arrangements (Kirlin et al. 1977, 134). Because contracting out reduces the size of public work forces, one would expect public employees to resist it. The importance of this obstacle depends on the political strength of public employees. The strength can be general and/or service-specific. For instance, public employees as a whole might be mobilized and thus work to resist 
external production in general, or particular groups of public employees (e.g., public safety officers) might be organized and seek only to impede contracting for services related to their employment. Internal political pressure is measured by the number of city employees per 1,000 population.

\section{Legal Constraints}

Finally, legal restrictions have not been considered as a principal independent variable in extant multivariate models of the decision to employ external service providers. Several studies do include legislatively imposed tax limits (Ferris 1986; Ferris and Graddy 1988; Morgan et al. 1988), but tax restrictions represent only one of several types of limitations that might be imposed by a higher authority. Straussman and Farie (1981), for example, note the abundance of state and federal regulations that complicate contracting out for social services at the local level. Thus, the stringency of such regulations may significantly affect the number and kind of contracts in a given jurisdiction.

The legal framework for most types of formal interlocal cooperation is established by state constitutional and statutory provisions. Such laws provide local governments with the authority to negotiate intergovernmental arrangements within legally established limits. Even though constitutional and statutory provisions differ considerably from state to state, most include requirements that localities must fulfill before entering into intergovernmental arrangements.

A legal variable will be included as a way of representing various state laws and regulations that might inhibit the use of intergovernmental agreements. This measure has been created from tables in the ACIR (1985) study, in the following manner. Cities in states with laws authorizing intergovernmental contracts were given a score of 1 ; then five provisions limiting intergovernmental agreements were subtracted from that initial score. ${ }^{1}$ The calculation was then reversed to produce a variable where larger numbers indicate greater restrictions on the power to contract (with a range of 0 to 4 ).

\section{Data and Methods}

The data for this study are derived from the results of a mail questionnaire conducted jointly by the Advisory Commission on Intergovernmental Relations (ACIR) and the International City Manage- 
ment Association (ICMA) during the summer of 1983. The survey generated data on 42 local government services delivered to citizens. These services cover five broad functional areas: public works, public safety, health and human services, parks and recreation, and general support services. ${ }^{2}$ The respondents were asked whether or not their government purchased the delivery of any of these services from another government through a written or unwritten service agreement.

In the following analysis, these data will be merged with information derived primarily from the 1983 County and City Data Book, which contains a range of social, economic, and fiscal data for cities of over 25,000 in population. The total number of cities in the analysis is 614 .

Two major decision rules were established which guided the selection of the 614 cases in the analysis. First, it was decided to incorporate only those cities with a population of 25,000 and above in the analysis. ${ }^{3}$ The exclusion of cities with populations below 25,000 was based on the notion that very small communities often may be forced into various contractual and intergovernmental arrangements because of their size. The degree of contracting, then, is likely to be significantly affected by city size. By including only those cities with a population of 25,000 and over, a city size bias to some extent can be avoided. ${ }^{4}$ A second decision was to exclude counties in this research. Even though counties were surveyed in the larger sample on which this study is based, it was decided to exclude them from the empirical analysis owing to their distinctive role in the service delivery process. ${ }^{5}$

The degree of intergovernmental contracting by a city is measured as a proportion of all services provided by the municipality. It is most appropriate to examine contracting as a proportion of all services provided by a government because this procedure removes the effect of functional scope from the contracting measure. Since functional scope is strongly related to population size (Stein 1981), a measure of contracting unadjusted for functional scope risks producing ambiguous results.

The dependent measure of intergovernmental contracting will be divided into two separate types of intergovernmental agreements: (1) the percentage of publicly provided services that are contracted out entirely to another unit of government, and (2) the percentage of publicly provided services that are produced jointly with another government. Prior evidence suggests that variations may exist among cities that decide whether to engage in exclusive contracting as opposed to joint contracting (Valente and Manchester 1984; ACIR 1985). 
Relevant characteristics of the 614 municipalities should be provided here. Table 1 shows that over 80 percent of the cities in the

Table 1. Characteristics of the 614 Municipalities Included in the Analysis

Number of Cities Percent

$\begin{array}{ccr}\text { Population Category } & & \\ 500,000 \text { and over } & 10 & 1.8 \\ 250,000-499,999 & 18 & 2.9 \\ 100,000-249,999 & 72 & 11.7 \\ 50,000-99,999 & 160 & 26.0 \\ 25,000-49,999 & 354 & 57.6\end{array}$

Geographic Regions ${ }^{a}$

$\begin{array}{lll}\text { Northeast } & 104 & 16.9\end{array}$

North Central $\quad 172 \quad 28.1$

South $\quad 163 \quad 26.5$

$\begin{array}{lll}\text { West } & 175 & 28.5\end{array}$

Metro Status ${ }^{b}$

Central

Suburban 263

Independent

277

45.1

Form of Government

Mayor-Council

165

26.8

Council-Manager

427

69.6

Commission

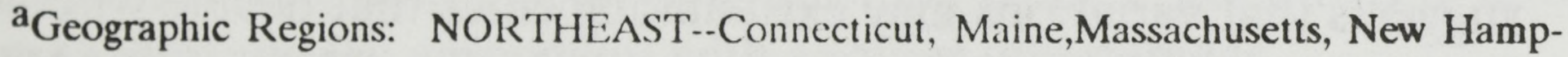
shire, New Jersey, New York, Pennsylvania,Rhode Island, Vermont; NORTH CENTRAL-Illinois, Indiana, Iowa, Kansas, Michigan, Minnesota, Missouri, Nebraska, North Dakota,Ohio, South Dakota, and Wisconsin; SOUTH--Alabama, Arkansas,Delaware, Florida, Georgia, Kentucky, Louisiana, Maryland,Mississippi, North Carolina, Oklahoma, South Carolina, Tennessee, Texas, Virginia, and West Virginia; WEST--Alaska, Arizona,California, Colorado, Hawaii, Idaho, Montana, Nevada, New Mexico, Oregon, Utah, Washington, and Wyoming.

b Metro Status: CENTRAL--the city(ies) actually appearing in the MSA title; SUBURBAN--the city(ies) located within an MSA; INDEPENDENT--the city(ies) not located within an MSA.

analysis had populations under 100,000. Overall, the average (mean) size of the municipalities was 92,412 (median $=44,810)$. The regional breakdown shows that the cities were somewhat proportionately distributed, with the greatest number being from the West (175). Finally, nearly 90 percent of the municipalities in the analysis were either suburban or independent cities, and nearly 70 percent employed the council-manager form of government (427). 


\section{Findings}

Does government structure have an impact on the use of intergovernmental service arrangements by municipalities? Table 2 shows the percentage of cities with at least one intergovernmental service agreement (service contract or joint agreement) by the three governmental structure measures: (1) form of government, (2) type of ballot, and (3) type of electoral representation. Apparently, those cities with more reform-oriented structures are more likely to enter into a service agreement with other governmental entities than their unreformed counterparts. When looking at the relationship by form of government, cities that operate under a council-manager form of government are more inclined than cities governed otherwise to seek out other governments as service providers (chi square $=19.93$ ). This finding supports the argument that the presence of a city manager tends to contribute to a municipality's willingness to pursue alternative urban service delivery approaches when faced with fiscal stress. Finally, those cities which use nonpartisan ballots for local elections are significantly more likely to contract out with other governments (chi square = 26.78). This is not surprising since most cities use nonpartisan ballots in conjunction with a council-manager form of government.

While Table 2 reveals that government structure appears to affect the use of intergovernmental service agreements by municipalities, it does not distinguish between the two primary types of service agreements: service contracts and joint agreements. Prior evidence suggests that variations may exist among cities that decide whether to engage in exclusive or joint contracting behavior (Valente and Manchester 1984; ACIR 1985). Therefore, differences may occur whenever the relationship between government structure and the two types of intergovernmental arrangements are analyzed.

Tables 3 and 4 make such a distinction by focusing on intergovernmental service contracts and joint service agreements, respectively. First, when examining the relationship between governmental service contracting in Table 3 , significant differences are present among all three structural measures. Once again, those cities in which reform components are present tend to contract out services with other governmental entities at significantly greater rates than those where reform structures are absent. Finally, Table 4 shows that even though the differences within the structural measures are not as great for joint service agreements (as represented by lower chi-squares), two of the 
Service Agreements

Table 2. Percentage of Cities With Intergovermental Service Arrangements by Form of Government, Ballot Type, and Type of Electoral Representation

\begin{tabular}{|c|c|c|}
\hline $\begin{array}{l}\text { Total No. } \\
\text { of Cities }\end{array}$ & $\begin{array}{c}\text { Government Structure } \\
\text { Variables }\end{array}$ & $\begin{array}{l}\% \text { of Cities with } \\
\text { Joint Agreements }\end{array}$ \\
\hline \multicolumn{3}{|c|}{ Form of Government } \\
\hline 424 & Council-Manager & $81.4(345)$ \\
\hline 191 & $\begin{array}{l}\text { Mayor-Council or } \\
\text { Commission }\end{array}$ & $64.4(123)$ \\
\hline \multicolumn{3}{|c|}{ Chi-Square $=19.93^{* *}$} \\
\hline & Type Of Ballot & \\
\hline 435 & Nonpartisan Elections & $82.3(358)$ \\
\hline 121 & Partisan Elections & $59.5(72)$ \\
\hline \multicolumn{3}{|c|}{ Chi-Square $=26.78^{* *}$} \\
\hline & Representation & \\
\hline 351 & At-Large & $80.3(282)$ \\
\hline 183 & Ward or Combination & $74.3(136)$ \\
\hline & \multicolumn{2}{|c|}{ Chi-Square $=2.18$} \\
\hline
\end{tabular}

${ }^{*} \mathrm{p}<.05$

$* * p<.01$

three structural measures (form of government and ballot type) are significant. Cities with a council-manager form of government and nonpartisan elections display a significantly greater propensity to enter into a joint service agreement with another government.

Overall, it appears that government structure does have an effect on whether cities engage in some form of intergovernmental contracting (either jointly or wholly). Reform cities are considerably more likely to enter into such an agreement than those with unreformed structures. $^{6}$

As previously discussed, however, it is possible that other factors besides government structure significantly influence a city's decision on whether to turn to other governments as an alternative to local service production. For instance, Ferris (1986) contends that the use of external providers increases when (1) cost savings are expected, (2) fiscal pressures are great, and (3) political opposition is relatively weak. Furthermore, the stringency of state imposed legal requirements, even 
Table 3. Percentage of Cities With Intergovernmental Service Contracts by Form of Government, Ballot Type, and Type of Electoral Representation

\begin{tabular}{|c|c|c|}
\hline $\begin{array}{l}\text { Total No. } \\
\text { of Cities }\end{array}$ & $\begin{array}{c}\text { Government Structure } \\
\text { Variables }\end{array}$ & $\begin{array}{l}\% \text { of Cities with } \\
\text { Service Contracts }\end{array}$ \\
\hline & Form of Government & \\
\hline 424 & Council-Manager & $68.9(292)$ \\
\hline 191 & $\begin{array}{l}\text { Mayor-Council or } \\
\text { Commission }\end{array}$ & $50.3(96)$ \\
\hline & \multicolumn{2}{|c|}{ Chi-Square $=18.79^{* *}$} \\
\hline & Type Of Ballot & \\
\hline 435 & Nonpartisan Elections & $68.5(298)$ \\
\hline 121 & Partisan Elections & $48.8(59)$ \\
\hline & \multicolumn{2}{|c|}{ Chi-Square $=15.21^{* *}$} \\
\hline & $\begin{array}{l}\text { Type of Electoral } \\
\text { Representation }\end{array}$ & \\
\hline 351 & At-Large & $68.7(241)$ \\
\hline 183 & Ward or Combination & $57.9(106)$ \\
\hline & \multicolumn{2}{|c|}{ Chi-Square $=5.52^{*}$} \\
\hline
\end{tabular}

${ }^{*} \mathrm{p}<.05$

$* * p<.01$

though not considered extensively in previous research, might also help shape a city's contracting behavior.

In order to assess simultaneously the independent effects of government structure, supply factors, fiscal pressures, political influences, and legal constraints on the use of intergovernmental service agreements, Multiple Classification Analysis (MCA) is employed. In the analysis, the dependent variable is divided into two separate types of intergovernmental agreements: (1) the percentage of publicly provided services that are contracted out entirely to another unit of government; and (2) the percentage of publicly provided services that are produced jointly with another unit of government.

Table 5 summarizes the MCA results for intergovernmental service contracting. ${ }^{7}$ According to the $\mathrm{MCA}$, three variables have a statistically significant effect on intergovernmental service contracting: structural reform, metropolitan status, and percentage of elderly population. As hypothesized, reform cities are more inclined to contract out 
Service Agreements

Table 4. Percentage of Cities With Intergovernmental Joint Agreements by Form of Government, Ballot Type, Type of Electoral Representation

\begin{tabular}{|c|c|c|}
\hline $\begin{array}{l}\text { Total No. } \\
\text { of Cities }\end{array}$ & $\begin{array}{c}\text { Government Structure } \\
\text { Variables }\end{array}$ & $\begin{array}{l}\text { \%of Cities with } \\
\text { Joint Agreements }\end{array}$ \\
\hline & \multicolumn{2}{|l|}{ Form of Government } \\
\hline 424 & Council-Manger & $60.4(256)$ \\
\hline \multirow[t]{3}{*}{191} & Mayor-Council for & $47.6(91)$ \\
\hline & \multicolumn{2}{|c|}{ Chi-Square $=8.17^{* *}$} \\
\hline & Type of Ballot & \\
\hline & Nonpartisan Elections & $61.1(266)$ \\
\hline \multirow[t]{3}{*}{121} & Partisan Elections & $45.4(55)$ \\
\hline & \multicolumn{2}{|c|}{ Chi-Square $=8.92^{* *}$} \\
\hline & $\begin{array}{l}\text { Type of Electoral } \\
\text { Representation }\end{array}$ & \\
\hline \multirow{3}{*}{$\begin{array}{l}351 \\
183\end{array}$} & $\overline{\text { At-Large }}$ & $59.5(209)$ \\
\hline & Ward or Combination & $53.6(98)$ \\
\hline & \multicolumn{2}{|c|}{ Chi-Square $=1.47$} \\
\hline
\end{tabular}

$* \mathrm{p}<.05$

$* * p<.01$

with other governments than those cities utilizing unreformed structures. Second, cities outside metropolitan areas are least likely to enter into a service contract with another unit of government. The lack of available suppliers is obviously a critical factor in deciding whether to enter into such a contract for nonmetropolitan areas, even though these areas might be in dire need of scale economies. Finally, cities with a large elderly population are also least likely to contract out local services to other governments. Because of their growing political strength and sensitivity to potential changes in the level or quality of public services, elderly groups may be able to exert enough political pressure to impede changes in the traditional service delivery status quo. In total, the six variables employed in the analysis explain 12 percent of the variation in intergovernmental contracting behavior among these 614 cities.

Table 6 shows the MCA results for joint service agreements. Only one variable, state statutory limitations, reaches statistical significance. Most state statutes pertaining to joint agreements are not only broad in 
Table 5. Effects of Government Structure, Supply, Fiscal, Political, and Legal Variables on Intergovernmental Service Contracts: A Multiple Classification Analysis $(\mathrm{N}=614)$

\begin{tabular}{lcccc}
\hline & \multicolumn{4}{c}{ Dependent Variable: Service Contracts } \\
\cline { 2 - 5 } Variables and Categories & $\begin{array}{c}\text { Unadjusted } \\
\text { Mean }\end{array}$ & Eta & $\begin{array}{c}\text { Adjusted } \\
\text { Mean }\end{array}$ & Beta \\
\hline
\end{tabular}

Government Structure ${ }^{a}$

Structural Reform

No Reform Element

5.62

6.29

One Reform Element

3.46

4.03

Two Reform Elements

5.29

5.68

Three Reform Elements

8.11

$.22^{* *}$

8.65

Supply (Cost Savings)

Metropolitan Status

NONMSA

MSA

4.80

5.34

7.16

$.13^{*}$

6.94

$.09^{*}$

Fiscal Pressures

Tax Limitations

No Tax Limits

Tax Limits

5.36

6.08

8.21

.17

7.12

.06

Political Pressures $^{b}$

Community Pressure

$\%$ Elderly Population

Small (0-9.9)

8.39

8.02

Medium (10.0-15.0)

6.36

6.66

Large (over 15.0)

4.61

$.19^{* *}$

4.68

$.17^{* *}$

Internal Pressure

City Employees $c$

Small (0-9.9

8.23

6.67

Medium (10.0-20.0)

4.92

5.40

Large (over 20.0)

6.00

.17

7.37

.10

Legal Constraints

State Statutory Limits

No Legal Restrictions

Legal Restrictions

8.14

5.36

.17

7.22

5.99

.08

Grand Mean

6.49

Multiple $\mathrm{R}=.34$

$\mathrm{R}^{2}=.12$

${ }^{\text {a }}$ Reform elements are represented by the presence of a city manager, at-large elections, and nonpartisan ballots.

${ }^{b}$ Low income and percent black variables were included in prior analyses, but had no contributory effect.

${ }^{\mathrm{c}}$ The number of city employees per 1,000 residents. 
Table 6. Effects of Government Structure, Supply, Fiscal, Political, and Legal Variables on Intergovernmental Joint Agreements: A Multiple Classification Analysis $(\mathrm{N}=614)$

\begin{tabular}{lcccc}
\hline & \multicolumn{4}{c}{ Dependent Variable: Service Contracts } \\
\cline { 2 - 5 } Variables and Categories & $\begin{array}{c}\text { Unadjusted } \\
\text { Mean }\end{array}$ & Eta & $\begin{array}{c}\text { Adjusted } \\
\text { Mean }\end{array}$ & Beta \\
\hline
\end{tabular}

Government Structure ${ }^{a}$

Structural Reform

No Reform Element

2.58

2.63

One Reform Element

4.57

4.12

Two Reform Elements

4.27

4.28

Three Reform Elements

5.07

5.19

.12

Supply (Cost Savings)

Metropolitan Status

NONMSA

5.13

4.83

MSA

4.39

.05

4.51

.02

Fiscal Pressures

Tax Limitations

No Tax Limits

4.36

4.26

Tax Limits

4.96

.05

5.12

.07

Political Pressures $b$

Community Pressure

$\%$ Elderly Population

Small (0-9.9)

4.34

4.32

Medium (10.0-15.0)

5.35

Large (over 15.0)

4.04

.09

5.24

4.19

.08

Internal Pressure

City Employees ${ }^{c}$

Small (0-9.9

4.43

5.54

Medium (10.0-20.0)

4.53

4.37

Large (over 20.0)

4.87

.03

4.90

.04

Legal Constraints

State Statutory Limits

No Legal Restrictions

Legal Restrictions

3.89

5.09

$.10^{*}$

3.56

5.31

$.14^{*}$

Grand Mean

4.60

Multiple $\mathrm{R}=.20$

$\mathrm{R}^{2}=.04$

${ }^{a}$ Reform elements are represented by the presence of a city manager, at-large elections, and nonpartisan ballots.

${ }^{\mathrm{b}}$ Low income and percent black variables were included in prior analyses, but had no contributory effect.

${ }^{\mathrm{C}}$ The number of city employees per 1,000 residents. 
nature but also impose few procedural requirements, while statutes relating to service contracting, on the other hand, tend to be more specific in language and impose much more stringent procedural requirements. Therefore, cities operating under strictly imposed legal requirements are more likely to turn to the joint production of a service with another government. The influence of governmental structure, supply factors, fiscal pressures, and political influences apparently does not seem to matter when cities decide to enter into a joint agreement with another government for the provision of a service. Overall, the variables employed explain only 4 percent of the variation in such contracting behavior. Obviously, significantly different considerations exist for joint service agreements than for service contracting.

\section{Summary and Broader Implications of Study}

This research has attempted to determine whether municipal government structure has an effect on the use of intergovernmental service arrangements by local governments. Evidence from the bivariate analyses suggests that government structure does seem to make a difference, with reform governments making greater use of intergovernmental arrangements.

Multivariate analyses indicate that municipal governments with reform structures are much more likely to engage in intergovernmental service contracting than their unreformed counterparts. Furthermore, evidence shows that the lack of available suppliers and political influences are often significant determinants that may impede a city's decision to contract with other governments. When considering joint contracting, government structure does not appear to be an important factor. State imposed legal restrictions is the only factor which significantly influences a city's decision to contract jointly with another government.

Three broader implications are associated with findings reported here. First, and perhaps most obviously, the presence of a city manager (along with other structural reform characteristics) is an important factor influencing cities to turn to other units of government for the delivery of services. Interlocal cooperation can be spurred on by a host of factors. Such reasons might include achieving economies of scale, eliminating negative externalities, standardizing services across govern- 
mental jurisdictions, or solving common problems that may arise from time to time. Whatever the reason may be for the pursuit of intergovernmental agreements, cooperation is much greater among those municipalities with a council-manager form of government. Apparently, the standardized professional training of city managers and the horizontal lines of communication between them under "picket-fence federalism" facilitate municipal cooperation, whereas such cooperation by unreformed council-mayor municipalities probably must await the arrival of political entrepreneur-types much like those envisioned by Salisbury (1969).

Second, cost factors (a city's metropolitan status) do appear to exert some influence on a city's decision to contract out with another government. For instance, if the community lies within a metropolitan area, it is much more likely to have found other governmental jurisdictions with which to contract. Cost savings, then, are more likely to be realized by metropolitan communities because of such factors as competition and economies of scale. The above average use of intergovernmental arrangements by the larger, more urbanized jurisdictions also indicates that they are useful tools for meeting problems in their more complex local settings. On the other hand, cities lying outside the metropolitan area are not afforded such a luxury because external suppliers are usually limited. When intergovernmental service contracts are considered by nonmetropolitan cities, county government is usually the only alternative service provider available. As a result, efficiency gains for a nonmetropolitan municipality may be minimal. In short, a well developed external market (e.g., available suppliers) is a prerequisite for intergovernmental contracting to be considered an attractive service production option.

Finally, stringently imposed statutory and constitutional requirements regarding interlocal agreements were found to significantly inhibit the use of intergovernmental service arrangements by municipalities. However, several states have made considerable progress in expanding a city's legal authority to enter into both joint service agreements and complete service contracts with other governments. Thus, from an intergovernmental perspective, it is noteworthy that states have been responsive to municipalities by creating a more conducive legal environment for the use of these alternative service delivery mechanisms.

In all, a number of quite diverse forces appear to shape a city's decision to contract out local services to other governmental units. 
Government structure, supplier availability, political influences, and legal constraints are all important considerations. Other less easily measured influences such as high capital start-up costs, extensive collective bargaining and hiring restrictions, the need for back-up forces, and the desire to maintain some degree of standardized service quality across jurisdictions may also be decisive. Further research must identify and measure such sources of influence so as to add significantly to our understanding of the intergovernmental contracting process.

\section{NOTES}

${ }^{1}$ The formula is as follows: add column 2 from table 3-1; subtract column 5 from table 3-1 and columns 5-8 from table 3-2. The five statutory provisions limiting intergovernmental contracts were: (1) a mutuality of powers provision; (2) approval of local governing bodies; (3) approval of state Attorney General; (4) terms of negotiation specification; and (5) resolution ordinances required.

${ }^{2}$ The 42 government services in which responses were solicited include: Public Works-street and bridge construction/maintenance, traffic signal installation/maintenance, building and plumbing inspection/code enforcement, refuse collection, solid waste disposal, sewage disposal, street lighting, water supply, air pollution control, paratransit operation, mass transit system operation, airport operation; Public Safety-police patrol, crime lab and identification, police/fire communications, police/fire training, fire prevention/suppression, jail/detention homes, emergency medical/ambulance services; Health and Human Services--public health clinics, hospitals, sanitary inspection, alcohol and drug rehabilitation, mental health services, child welfare, day care facilities, programs for the elderly, public housing operation and maintenance, animal control, insect/rodent control; Parks and Recreation--parks, recreational facilities, libraries, museums; Support Services--computer and data processing services, planning/zoning, building and grounds maintenance, tax assessing, tax/utility bill processing, engineering/ architectural services, fleet management/vehicle maintenance, general support services (e.g., legal, personnel, secretarial).

${ }^{3}$ The County and City Databook provides only limited demographic information and financial data for cities and counties with a population below 25,000. Missing data would present methodological problems at all stages of analysis if smaller communities were included in the sample.

${ }^{4}$ Research has shown that cities under 25,000 in population can realize significant economies of scale for almost all services, but that such economies begin to diminish for cities larger than 25,000 (Bish and Ostrom 1973). Therefore, any biases resulting from significant increases in contracting behavior among smaller jurisdictions because of scale economies can be avoided by excluding cities with a population lower than 25,000 .

${ }^{5}$ The analysis of county contracting is the subject of our future research.

${ }^{6}$ We wish to thank an anonymous reviewer who suggested that we examine the impact of reform elements by population categories. Analyses by population categories (e.g., $25,000-49,000 ; 50,000-99,999 ; 100,000-249,999 ; 250,000-499,999 ; 500,000$ and 